\title{
Effect of nutrient levels and schedule of nutrient application on the grain quality of upland rice intercropped in coconut
}

\section{B.M. Suman}

Department of Agronomy, College of Agriculture, Vellayani, Kerala Agricultural University, Thiruvananthapuram- 695522 (Kerala), India

Raj K. Sheeja*

Coconut Research Station, Balaramapuram, Kerala Agricultural University, Thiruvananthapuram - 695501 (Kerala), India

\section{K. Prathapan}

Coconut Research Station, Balaramapuram, Kerala Agricultural University, Thiruvananthapuram - 695501 (Kerala), India

*Corresponding author. E-mail: sheejakraj70@gmail.com

\begin{abstract}
:
Field experiment was conducted at Coconut Research Balaramapuram, during Kharif 2017 to study the effect of nutrient levels and schedule of application on the quality parameters of upland rice intercropped in coconut. The experiment was conducted in randomized block design (RBD) with four different nutrient levels and four different schedules of nutrient application. Quality parameters like crude protein and starch content were significantly influenced by nutrient levels. The crude protein content was found to increase with increase in $\mathrm{N}$ level, however starch content was found to increase up to $70 \mathrm{~kg}$ $\mathrm{N}$ and $35 \mathrm{~kg} \mathrm{~K} \mathrm{ha}^{-1}$ and after that a decline in trend was observed. The highest crude protein content (8.38 per cent) was recorded with highest nutrient level, NPK @ 120:30:60 kg ha-1. However, lower nutrient level, NPK @ 70:30:35 kg ha ${ }^{-1}$ recorded higher starch content (85.03 per cent). Among the schedule of nutrient application, $\mathrm{N}$ applied in three equal splits (15 days after sowing (DAS), active tillering and panicle initiation stage), $\mathrm{P}$ as basal and $\mathrm{K}$ in two equal splits (15 DAS and panicle initiation stage) along with foliar application of 0.2 per cent zinc sulphate and 0.04 per cent sodium borate at 45 DAS recorded the highest crude protein (7.50 per cent) and starch content (84.17 per cent). The study clearly indicated that the increased level of $\mathrm{N}$ and $\mathrm{K}$ increased the protein content due to the active role of $\mathrm{N}$ and $\mathrm{K}$ in protein synthesis. However, high rate of $\mathrm{N}$ application decreased the starch content. In addition to the application of NPK, foliar nutrition of zinc sulphate and sodium borate at 45 DAS considerably improved the quality of grain by increasing the starch and protein content.
\end{abstract}

Keywords: Crude protein content, Nutrient levels, Schedule of nutrient application, Starch content, Upland rice

\section{INTRODUCTION}

Rice is the oldest domesticated grain crop $(10,000$ years) and is the main energy source for more than 2.5 billion people. It provides 21 per cent of global human per capita energy and 15 per cent of per capita protein. Rice is cultivated in majority of the countries, with a total harvested area of about 160.75 million hectares, with an annual production of 488.23 Million metric tons (USDA, 2018). Considering its importance, the United Nations designated year, 2004 as the 'International Year of Rice'. Rice provides food for more than 65 per cent of the people living in India and is cultivated in an area of 433.88 lakh ha with an annual production of 104.32 $\mathrm{m} \mathrm{t}$ and productivity of $2404 \mathrm{~kg} \mathrm{ha}^{-1}$ (GOI, 2017). Grain quality is of prime importance in rice pro-

\section{Article Info}

DOI:10.31018/jans.v10i3.1801 Received: June 20, 2018

Revised: July 13, 2018

Accepted: July 28, 2018

\section{How to Cite}

Suman, B.M. et al. (2018). Effect of nutrient levels and schedule of nutrient application on the grain quality of upland rice intercropped in coconut. Journal of Applied and Natural Science, 10(3): 910 - 914 
pensable role in photosynthesis, activation of more than 60 enzymes (particularly enzymes responsible for starch and protein synthesis and also the production of adenosine triphosphate), osmoregulation etc. Potassium is described as the quality element ensuring optimum quality of agricultural produce. Potassium enhance the nutritive value of grains by elevating the protein content (IPI, 2013). Zinc is vital for various biochemical process like cytochrome and nucleotide synthesis, auxin metabolism, chlorophyll production and enzyme activation and it is crucial component for protein synthesis (IRRI, 2000). Rice yield can be consistently enhanced with boron fertilization which stimulate enzymatic activity, availability of sugar and respiration which revamp the pollen growth (Mohan et al., 2017).

Grain protein content progressively increased with the incremental doses of $\mathrm{N}$ and $\mathrm{P}$ (Murthy et al., 2015). Thao et al. (2015) observed that higher $N$ level increases the grain protein content of Bp53 rice variety and recorded the highest value at 120 $\mathrm{kg} \mathrm{N}$ ha $^{-1}$. Dwivedi et al. (2006) revealed that $\mathrm{K}$ fertilization increased the protein content of rice grain significantly. Potassium fertilization promoted the starch acquisition in rice (Ling et al., 2008). Same observations were also made by IPI (2013). Application of K@100 kg ha ${ }^{-1}$ increased the grain protein content but decreased the gel consistency (Thao et al., 2015). Li et al. (1999) observed that quality of rice grain was enhanced by $\mathrm{Zn}$ fertilization. Application of $\mathrm{Zn}$ along with $\mathrm{N}$ significantly enhanced the water absorption ratio and protein content of the grain (Khan et al., 2009). Application of $\mathrm{Zn}$ as basal and foliar application at flowering, milk and dough stages enhanced the crude protein and starch content in rice from 56.28 to 82.48 per cent and 5 to 19 per cent, respectively over control (Sudha and Stalin, 2015). The grain quality is enhanced by the application of B @ 0.75 $\mathrm{kg} \mathrm{ha}^{-1}$ (Rashid et al., 2009). Ahmad et al. (2012) reported that highest grain protein content (6.89 per cent) was recorded with the application of 1 per cent $B$ and highest grain starch content was obtained with the application of B and Si at 1 and 1.5 per cent, respectively. Keeping this in view the present study was undertaken with the objective to study the effect of nutrient levels and schedule of nutrient application on the quality parameters of rice grain of upland rice intercropped in coconut.

\section{MATERIALS AND METHODS}

The investigation was carried out in the Coconut Research Station, Balaramapuram, Thiruvananthapuram, Kerala, India during the Kharif season 2017. The experimental site is located at an altitude of $26 \mathrm{~m}$ above MSL with the geographical location at $8^{\circ} 22^{\prime} 52^{\prime \prime}$ North latitude and $77^{\circ} 1^{\prime} 47^{\prime \prime}$ East latitude. The total rainfall received during the cropping period was $884.3 \mathrm{~mm}$. The mean maxi- mum $\left(31.84{ }^{\circ} \mathrm{C}\right)$ and minimum temperature (19.57 ${ }^{\circ} \mathrm{C}$ ) were recorded during the crop season. The soil of the experimental site is red sandy loam, acidic in reaction (4.5), medium in organic carbon content (0.750), N (281.0 kg ha-1) and $\mathrm{K}(128.5 \mathrm{~kg}$ $\left.\mathrm{ha}^{-1}\right)$ and high in $\mathrm{P}\left(27.2 \mathrm{~kg} \mathrm{ha}^{-1}\right)$ status. The experiment was laid out in randomized block design with two factors. One factor was nutrient levels, comprised of four levels viz., $\mathrm{n}_{1}-60: 30: 30 \mathrm{~kg}$ $\mathrm{N}: \mathrm{P}: \mathrm{K} \mathrm{ha}^{-1}, \mathrm{n}_{2}-70: 30: 35 \mathrm{~kg} \mathrm{~N}: \mathrm{P}: \mathrm{K} \mathrm{ha}^{-1}, \mathrm{n}_{3}-$ 90:30:45 kg N:P:K ha ${ }^{-1}$ and $\mathrm{n}_{4}$-120:30: $60 \mathrm{~kg}$ $\mathrm{N}: \mathrm{P}: \mathrm{K} \mathrm{ha}^{-1}$ and other factor was schedules of nutrient application, comprised of four different schedules viz., $\mathrm{s}_{1}-\mathrm{N}$ in three equal splits(15 DAS, active tillering and panicle initiation stage) $+K$ in two equal splits (15 DAS and panicle initiation stage), $s_{2}-\mathrm{N}$ and $\mathrm{K}$ in three equal splits (15 DAS, active tillering and panicle initiation stage) and $P$ as basal, $s_{3}-s_{1}+$ zinc sulphate $(0.2$ per cent $)+$ sodium borate ( 0.04 per cent) as foliar spray at 45 DAS and $s_{4}-s_{2}+$ zinc sulphate $(0.2$ per cent $)+$ sodium borate ( 0.04 per cent) as foliar spray at 45 DAS. The variety used for the study was "Prathyasa" a short duration variety released from Rice Research Station, Moncompu. The seeds were dibbled @ $80 \mathrm{~kg} \mathrm{ha}^{-1}$ at a spacing of $20 \mathrm{~cm} \mathrm{x}$ $10 \mathrm{~cm}$. Fertilizers were applied in the form of urea, rock phosphate and muriate of potash as per the treatment schedule. Zinc sulphate (0.2 per cent) and sodium borate ( 0.04 per cent) were applied at 45 DAS, in addition to N, P and $\mathrm{K}$ as per the treatment schedule. The crop was raised as a rainfed crop. In order to avoid the moisture stress on crop growth and development the crop was irrigated to field capacity during non-rainy periods. Quality parameters like crude protein content was determined by the method suggested by Simpson et al. (1965) and starch content of the grain were analysed by the procedure developed by Aminoffet al. (1970). The data related to starch content was subjected to arc sine transformation. The data were analyzed statistically by using Analysis of Variance technique for RBD. The significance was tested using $F$ test and whenever, the $F$ values were found significant, critical difference was calculated at $5 \%$ probability level.

\section{RESULTS AND DISCUSSION}

Effect of nutrient levels and schedule of nutrient application on crude protein content: Nutrient levels significantly influenced the crude protein content, the most important quality determinant in rice (Table 1). With an increase in $\mathrm{N}$ levels, increase in crude protein content was observed. Significantly higher crude protein content (8.38 per cent) was recorded in $\mathrm{n}_{4}$ (NPK@ 120: 30: 60 kgha ${ }^{-1}$ ) which was followed by $n_{3}$ (NPK @ 90: 30: $45 \mathrm{~kg}$ $\left.\mathrm{ha}^{-1}\right)$. This might be due to higher $\mathrm{N}$ uptake resulting in higher $\mathrm{N}$ content in the grain. As $\mathrm{N}$ is the principal constituent of protein, protein content 
Table 1. Effect of nutrient levels and nutrient schedules on protein content of grain, per cent

\begin{tabular}{|c|c|c|c|c|c|c|}
\hline \multirow[t]{2}{*}{ Nutrient levels (N) } & \multicolumn{6}{|c|}{ Schedule of nutrient application (S) } \\
\hline & $s_{1}$ & $\mathbf{s}_{2}$ & $\mathbf{s}_{3}$ & & $\mathbf{s}_{4}$ & Mean \\
\hline $\mathrm{n}_{1}$ & 6.02 & 5.69 & 7.26 & & 5.69 & 6.17 \\
\hline $\mathrm{n}_{2}$ & 5.78 & 5.86 & 6.91 & & 7.96 & 6.68 \\
\hline$n_{3}$ & 6.04 & 6.74 & 8.14 & & 6.39 & 6.83 \\
\hline $\mathrm{n}_{4}$ & 7.88 & 8.75 & 7.70 & & 9.19 & 8.38 \\
\hline Mean & 6.43 & 6.76 & 7.50 & & 7.31 & \\
\hline & & & & $\operatorname{SEm}( \pm)$ & & \\
\hline Nutrient levels $(n)$ & & & & 0.197 & & \\
\hline Schedule of nutrient & $\mathrm{n}(\mathrm{s})$ & & & 0.197 & & \\
\hline Nutrient levels $\times$ Sch & utrien & $n(N \times S)$ & & 0.394 & & \\
\hline
\end{tabular}

Note: $\mathrm{n}_{1}-\mathrm{N}: \mathrm{P}: \mathrm{K} @$ 60:30:30 kg ha-1, $\mathrm{n}_{2^{-}} \mathrm{N}: \mathrm{P}: \mathrm{K} @$ 70:30:35 kg ha-1, $\mathrm{n}_{3^{-}} \mathrm{N}: \mathrm{P}: \mathrm{K} @$ 90: 30:45 kg ha-1, $\mathrm{n}_{4^{-}} \mathrm{N}: \mathrm{P}: \mathrm{K} @ 120:$ $30: 60 \mathrm{~kg} \mathrm{ha}^{-1} ; \mathrm{s}_{1}-\mathrm{N}$ in three splits (15 DAS, active tillering and panicle initiation stage), $\mathrm{P}$ as basal and $\mathrm{K}$ in two splits (15 DAS and panicle initiation stage), $s_{2}-\mathrm{N}$ and $\mathrm{K}$ in three splits (15 DAS, active tillering and panicle initiation stage) and $\mathrm{P}$ as basal, $\mathbf{s}_{3^{-}}$ $\mathrm{s}_{1}+$ foliar application of 0.2 per cent zinc sulphate and 0.04 per cent sodium borate at 45 DAS, $s_{4}-s_{2}+$ foliar application of 0.2 per cent zinc sulphate and 0.04 per cent sodium borate at 45 DAS.

Table 2. Effect of nutrient levels and nutrient schedules on starch content of grain, per cent.

\begin{tabular}{lccccc}
\hline \multirow{2}{*}{$\begin{array}{l}\text { Nutrient } \\
\text { levels (N) }\end{array}$} & \multicolumn{4}{c}{ Schedule of nutrient application (S) } \\
\cline { 2 - 5 } $\mathrm{n}_{1}$ & $\mathbf{s}_{\mathbf{1}}$ & $\mathbf{s}_{\mathbf{2}}$ & $\mathbf{s}_{\mathbf{3}}$ & $\mathbf{s}_{\mathbf{4}}$ & Mean \\
$\mathrm{n}_{2}$ & $80.74(63.95)$ & $78.67(62.47)$ & $84.80(67.04)$ & $82.52(65.27)$ & $81.69(64.68)$ \\
$\mathrm{n}_{3}$ & $84.38(66.70)$ & $83.75(66.21)$ & $86.54(68.46)$ & $85.45(67.56)$ & $85.03(67.23)$ \\
$\mathrm{n}_{4}$ & $80.91(64.16)$ & $77.59(61.72)$ & $84.37(66.69)$ & $81.33(64.38)$ & $81.05(64.24)$ \\
Mean & $79.61(63.14)$ & $81.16(64.26)$ & $80.94(64.09)$ & $80.15(66.62)$ & $80.15(66.62)$ \\
\hline
\end{tabular}

Values in parentheses are original values; values are subjected to arc sine transformation

\begin{tabular}{lll}
\hline & SEm ( $\mathbf{\pm})$ & CD (0.05) \\
\hline Nutrient levels (N) & 0.301 & 0.874 \\
Schedule of nutrient application (S) & 0.301 & 0.874 \\
Nutrient levels x Schedule of nutrient & 0.603 & 1.749 \\
application (N x S) & &
\end{tabular}

Note: $n_{1}-\mathrm{N}: \mathrm{P}: \mathrm{K} @$ 60:30:30 kg ha-1 $\mathrm{n}_{2^{-}} \mathrm{N}: \mathrm{P}: \mathrm{K} @$ 70:30:35 kg ha-1 $\mathrm{n}_{3}-\mathrm{N}: \mathrm{P}: \mathrm{K} @$ 90: 30:45 kg ha-1, $\mathrm{n}_{4^{-}} \mathrm{N}: \mathrm{P}: \mathrm{K} @ 120:$ $30: 60 \mathrm{~kg} \mathrm{ha}^{-1} ; \mathrm{s}_{1}-\mathrm{N}$ in three splits (15 DAS, active tillering and panicle initiation stage), $\mathrm{P}$ as basal and $\mathrm{K}$ in two splits (15 DAS and panicle initiation stage), $\mathrm{s}_{2}-\mathrm{N}$ and $\mathrm{K}$ in three splits (15 DAS, active tillering and panicle initiation stage) and $\mathrm{P}$ as basal, $\mathrm{s}_{3}-$ $\mathrm{S}_{1}+$ foliar application of 0.2 per cent zinc sulphate and 0.04 per cent sodium borate at 45 DAS, s4-S2 + foliar application of 0.2 per cent zinc sulphate and 0.04 per cent sodium borate at 45 DAS.

would always be in direct proportion with the $\mathrm{N}$ application rate (Javeed et al. 2017). It was also observed that under adequate supply of $\mathrm{N}$, more efficient low affinity transport system promotes greater transport of nitrate ions into rice plants which led to the translocation of more amount of $\mathrm{N}$ to the rice grain from the vegetative parts leading to enhanced crude protein content (Samonteet al., 2006; Chandel et al. 2010). Cai et al. (2008) observed that increased $\mathrm{N}$ availability and uptake stimulate the enzymes, nitrate reductase and glutamine synthase, which play a crucial role in the incorporation of absorbed $\mathrm{N}$ into amino acid during protein synthesis. This might be the plausible reason for higher crude protein content under higher nitrogen levels in the present study also. Thao et al. (2015) revealed that application of $\mathrm{N}$ @ $120 \mathrm{~kg} \mathrm{ha}^{-1}$ and $\mathrm{K} @ 80 \mathrm{~kg} \mathrm{ha}^{-1}$ increased the crude protein content in rice grain.

Schedule of nutrient application also significantly influenced the crude protein content of grain. The treatments with foliar spray of 0.2 per cent zinc sulphate and 0.04 per cent sodium borate $\left(s_{3}\right.$ and
$\mathrm{S}_{4}$ ) recorded higher crude protein (7.50 per cent and 7.30 per cent) content compared to other two treatments without the foliar spray of 0.2 per cent zinc sulphate and 0.04 per cent sodium borate $\left(s_{1}\right.$ and $s_{2}$ ). The reason might be due to the enhanced uptake of $\mathrm{N}$ for the greater assimilation of $\mathrm{N}$ and protein synthesis. Application of zinc sulphate as foliar spray might have enhanced the $\mathrm{N}$ metabolism which increased the accumulation of amino acids. The enhanced building up of amino acids increased the protein synthesis and protein content in grain as observed by Sudha and Stalin (2015). Boron also have an important role in amino acid formation, protein synthesis and translocation of assimilates (Tisdale et al., 1985; Gowthami et al., 2018). Mohan et al. (2017) reported that foliar application of $\mathrm{Zn}, \mathrm{B}$ and $\mathrm{S}$ along with recommended dose of fertilizers increased the protein content in rainfed rice.

The treatment combination $\mathrm{n}_{4} \mathrm{~s}_{4}$ (NPK @ 120:30:60 $\mathrm{kg} \mathrm{ha}^{-1}$ applied as $\mathrm{N}$ in three equal splits, $\mathrm{P}$ as basal and $K$ in three equal splits along with foliar spray of 0.2 per cent zinc sulphate and 0.04 per 
cent sodium borate at 45 DAS) recorded the highest crude protein content ( 9.19 per cent) in grains. This could be attributed to the increased uptake and higher content of $\mathrm{N}$ in the grain, which accelerates the protein synthesis and protein content in grain. Zinc sulphate application enhanced the Zn content and uptake in plant. Keram et al. (2014) observed that enhanced $\mathrm{Zn}$ concentration in plants trigger off the activity of RNA and ribosome which accelerated the protein synthesis.

Effect of nutrient levels and schedule of nutrient application on starch content: From the results it has been observed that, starch content was increased up to $70 \mathrm{~kg} \mathrm{~N} \mathrm{ha}^{-1}$ and $35 \mathrm{~K} \mathrm{ha}^{-1}$, further increase in $\mathrm{N}$ and $\mathrm{K}$ level decreased the starch content (Table 2). The result is in agreement with the findings of Javeed et al. (2017), who observed that amylose content of the rice grain was the highest with $40 \mathrm{~kg} \mathrm{~N} \mathrm{ha}^{-1}$ compared to 60 $\mathrm{kg} \mathrm{N} \mathrm{ha}^{-1}$. Starch is a polymer consisting of linear fraction, amylose and branched chain fraction, amylopectin. Hu-Lin et al. (2007) observed that protein content in rice grain enhanced with increased level of $\mathrm{N}$, but the amylose content decreased. Ling et al. (2008) also reported that both $\mathrm{N}$ and $\mathrm{K}$ fertilizer application promoted starch accumulation, but too much $\mathrm{N}$ fertilization had negative effect on starch accumulation. The high crude protein content in $\mathrm{n}_{3}$ (NPK @ 90:30:45 kg ha ${ }^{-1}$ ) and $\mathrm{n}_{4}$ (NPK@ 120: 30: 60 kg ha ${ }^{-1}$ ) may be the plausible reason for the lower starch content in these treatments.

Among the schedule of nutrient application, the higher starch content was observed in treatments with foliar spray of zinc sulphate and sodium borate $\left(s_{3}\right.$ and $\left.s_{4}\right)$. The high starch content observed in these treatments might be due to the favourable influence of $\mathrm{Zn}$ and $\mathrm{B}$ on starch formation. The mineral element $Z n$ has a very important regulatory role in carbohydrate metabolism (Broadley et al., 2007). The formation of energy rich compounds, NADPH or NADH is depend on the $\mathrm{Zn}$ concentration, which might have involved in tapping solar energy for photosynthesis and increased formation of starch and sugars (Sudha and Stalin, 2015). Ghasal et al. (2017) reported that soil application of $1.25 \mathrm{~kg} \mathrm{Zn-EDTA} \mathrm{+} 0.5 \mathrm{per}$ cent foliar spray at maximum tillering and booting stages resulted in higher grain yield and starch content in wheat. Though $B$ is needed in small amounts by the plant, it plays a vital role in carbohydrate transportation, fruit and seed development, cell division etc. (Guneset al., 2003). Several researchers reported that foliar nutrition of $B$ significantly increased the carbohydrate content in rice grain (Graget al., 2005; Ahmad et al., 2012; Narendra et al., 2015).

Interaction between nutrient levels and schedule of nutrient application was found significant. Application of NPK@ $@$ 70: 30: $35 \mathrm{~kg} \mathrm{ha}^{-1}$, applied as N in three equal splits, $P$ as basal and $K$ either in two splits or three splits along with foliar spray of 0.2 per cent zinc sulphate and 0.04 per cent sodium borate $\left(n_{2} s_{3}\right.$ and $\left.n_{2} s_{4}\right)$ recorded higher starch content of grain compared to other treatments. The reason might be the favourable influence of $\mathrm{Zn}$ and $\mathrm{B}$ on starch accumulation in rice grain under adequate $\mathrm{N}$ supply.

\section{Conclusion}

It can be concluded from the results that, nutrient levels and schedule of nutrient application had significant effect on quality parameters viz., crude protein and starch content of the grain. NPK applied @ 120: 30: 60 kg ha ${ }^{-1}$ recorded the highest crude protein content. Contrary to crude protein content, starch content increased up to $70 \mathrm{~kg} \mathrm{~N}$ and $35 \mathrm{~kg} \mathrm{~K}^{-1}$, further increase in $\mathrm{N}$ and $\mathrm{K}$ showed a decline in starch content. Foliar spray of zinc sulphate and sodium borate at 45 DAS enhanced the crude protein and starch content of the grain. Among the different schedule of nutrient application, application of $\mathrm{N}$ in three equal splits (15 DAS, active tillering and panicle initiation stage), $\mathrm{P}$ as basal, $\mathrm{K}$ in two equal splits (15 DAS and panicle initiation) along with foliar spray of zinc sulphate and sodium borate at 45 DAS registered the highest crude protein and starch content. The study clearly indicated that the high rate of $\mathrm{N}$ and $\mathrm{K}$ application increased the protein content of the grain, however, too much $\mathrm{N}$ fertilization decreased the starch content due to the negative impact on starch accumulation. Also, the foliar nutrition of micronutrients viz., $\mathrm{Zn}$ in the form of zinc sulphate ( 0.2 per cent) and $B$ in the sodium borate ( 0.04 per cent) at 45 DAS improved the grain quality of upland rice by enhancing the starch and protein content of the grain.

\section{REFERENCES}

1. Ahmad, A., Tahir, M., Ullah, E., Naeem, M., Ayub, M., Rehman, H., and Talha, M. (2012). Effect of silicon and boron foliar application on yield and quality of rice. Pak. J. life Soc. Sci. 10(2): 161-165.

2. Aminoff, D., Binkley, W. W., Schaffer, R., and Mowry, R. W. (1970). Analytical methods for carbohydrates. The carbohydrate: Chemistry and Biochemistry. Academic press, New York, pp. 760-764.

3. Bao, J.S. and Xia, Y.W. (2000). Effects of genotypexenvironment interaction on eating and cooking quality of indica rice. J. Zhejiang Univ. Agri. Life Sci. 26: 144-150.

4. Broadley, M.R., White, P.J., Hammond, J.P., Zelko, I., and Lux, A. (2007). Zinc in plants. New phytol. 173: $677-702$.

5. Cai, C., Wang, J.Y., Zhu, Y.G., Shen, Q., Li, B., Tong, Y.P., and Li Z, S. (2008). Gene structure and expression of high affinity nitrate transport system in rice roots. J. Integ. Plant Biol. 50 (4): 443-451. doi: 10.1111/j.1744-7909.2008.00642.x. ...

6. Chandel, G., Banerjee, S., See, S., Meena, R., Sharma, D.J., and Verulkar, S.B. (2010). Effect of different 
nitrogen fertilizer levels and native soil properties on rice grain $\mathrm{Fe}, \mathrm{Zn}$ and protein contents. Rice Sci. 17 (3): 213-227.doi.org/10.1016/S1672-6308(09)600202

7. Dwivedi, A.P., Dixit, R.S., and Singh, G.R. (2006). Effect of nitrogen, phosphorus and potassium levels on growth, yield and quality of hybrid rice. Agric. Sci. Digest. 25 (4): 309-310.

8. Ghasal, P.C., Shivay, Y.S., Pooniya, V., Choudhary, M., and Verma, R.K. (2017). Response of wheat genotypes to zinc fertilization for improving productivity and quality. Arch. Agron. Soil Sci. 63(11): 1597: 1612.doi.org/10.1080/03650340.2017.1289515

9. GOI [Government of India, Ministry of Agriculture and Farmers' Welfare]. (2017). Annual Report 20162017. Government of India, Ministry of Agriculture and Framer's Welfare, Krishibhavan, New Delhi, pp.194.

10.Gowthami, P., Rao, G.R., Rao, K.L.N., and Lal, A.M. (2018). Effect of foliar application of potassium, boron and zinc on quality and seed yield in soybean. Int. J. Chem. Stud. 6 (1): 142-144.

11.Grag, O.K., Sharma, A.N., and Kona, G.R.S.S. (2005). Effect of boron on the pollen viability and yield of rice plants (Oryza sativa L. var. Jaya). Plant Soil. 52: 591-594.

12.Gunes, A., Alpalsan, M., Inal, A., Adak, M.S., Eraslan, F., and Cicek, N. (2003). Effects of boron fertilization on the yield and some yield components of bread and durum wheat. Turkish J. Agric. For. 27: 329-335.

13.Hu-Lin, H., You-Zhang, W., Xiao-E, Y., Ying, F., and Chung-Yong, W. (2007). Effects of different nitrogen fertilizer levels on $\mathrm{Fe}, \mathrm{Mn}, \mathrm{Cu}$ and $\mathrm{Zn}$ concentrations in shoot and grain quality in rice (Oryza sativa). Rice Sci. 14(4): 289-294.

14.IPI [The International Potash Institute]. (2013). Potassium - the quality element in crop production. Retrieved April $30 \quad 2018$ from https:/ www.ipipotash.org/.../406.Potassium-the-qualityelement-in-cropproduction. p...

15.IRRI [International Rice Research Institute]. (2000). Nutritional disorders and nutrient management in rice. International Rice Research Institute, Manila, Philipines.

16.Javeed. A., Gupta, M., and Gupta, V. 2017. Effect of graded levels of N,P and K on growth and quality of fine rice cultivar (Oryza sativa L.) under subtropical conditions. Sci. Soc. Adv. Res. Soc. Change Int. J. Manag. 3(1):18.Retrieved April 032018 from http:// www.ssarsc.orgdocuments/1management_effect_gra ded_levels24_4_17.pdf

17.Keram, K.S., Sharma, B.L., Kewat, M.L., and Sharma, G.D. (2014). Effect of zinc fertilization on growth, yield and quality of wheat grown under agro-climatic condition of Kymore plateau of Madhya Pradesh. India. The Bioscan. 9 (4): 1479-1483.

18.Khan, R., Gurumani, A.R., Khan, M.S., and Gurumani, A.H. (2009). Residual, direct and cumulative effect of zinc application on wheat and rice yield under ricewheat system. Soil. Environ. 28 (1): 24-28.

19.Li., Yan., Qin., Suichu., Li, Y., and Qin, S.C. (1999).
Effect of rice metabolism and the diagnosis of hidden zinc deficiency in rice. J. Fujian Agric. Univ. 28(1):6667

20.Ling, Z., Chong-Hua, X.I.E., Wei, L.I., and Guo-tao, Y. (2008). Effect of nitrogen and potassium on starch content and activities of starch synthase in grain of hybrid rice BYOU. Chinese. J. Rice Sci. 22 (5): 551 554

21.Mo, H.D. (1993). Quality improvement of rice grain in China. Sci. Agric. Sin. 26: 8-14.

22.Mohan, A., Tiwari, A., Kumar, M., Pandey, D., Singh, A., and Singh, B. (2017). Effect of foliar spray of various nutrients on performance of rainfed rice (Oryza sativa L.). J. of pharmacognosy and phytochem. 6 (5): $\quad 2252-2256 . \quad$ doi.10.13140/RG.2.2.24110. 41283

23.Murthy, K.M.D., Rao, A.U., Vijay, D., and Sridhar, T.V. (2015). Effect of levels of nitrogen, phosphorous and potassium on performance of rice. Indian $\mathrm{J}$. Agric. Res. 49 (1): 83-87.

24.Narendra, K., Ritika, M., Shankdhar, S.C., and Deepti, S. (2015). Effect of foliar application of boron on growth, yield, chlorophyll, amylose and nitrate reductase activity in rice. Oryza. 52 (2): 123-130.

25.Nawaz, M., Wahla, A.J., Kashif, M.S., Waqar, M.Q., Ali, M.A., and Chadhar, A.R. (2017). Effect of exogenous nitrogen levels on the yield of rice grain in Sheikhpura, Pakistan. Pakist. J. Agric. Res. 30 (1): 85-92.

26.Rashid, A., Yasin, A. and Ali, M.A. (2009). Boron deficiency in rice in Pakistan: A serious constraint to productivity and grain quality, In: Ashraf, M., Ozturk, M. and Athar, H.R. (eds), Salinity and Water Stress: Improving Crop Efficiency, Springer Science + Business Media, pp.213-219.

27.Samonte, S.O.P.B., Wilson, L.T., Medley, J.C., Pinson, S.R.M., Clung, A.M.M.C., and Lales, J.S. (2006). Nitrogen utilization efficiency: relationships with grain yield, grain protein, and yield related traits in rice. Agro. J. 98: 168-176.

28.Simpson, J. E., Adair, C. H., Kohler, G. O., Dawson, E. N., Debald, H. A., Kester, E. B. and Klick, J. T. (1965). Quality evaluation studies of foreign and domestic rice. Tech. Bull. No.1331. Services, U.S.D.A., pp.1-86.

29.Sudha, S. and Stalin, P. (2015). Effect of zinc on yield, quality and grain zinc content of rice genotypes. Int. J. Farm Sci. 5 (3): 17-27.

30.Thao, H.M., Hong, N.H., Tuyen, N.T., Toan, N.V., and Quyen, L.N. (2015). Study on the effect of some of $\mathrm{N}, \mathrm{P}, \mathrm{K}$ fertilizer compounds on the yield and quality of Bp53 rice variety. J. Agric. Tech. 11(8): 21492156.

31.Tisdale, S.L., Nelson, W.L., and Beaton, J.D. (1985). Soil fertility and fertilizers ( $4^{\text {th }}$ edn.), Mac Millon.

32.USDA [United States Department of Agriculture]. (2018). World: Rice Area, yieldandproduction. Retrieved May 282018 from http://apps.fas.usda.gov/ psdoline/reportHandler.ashx?.

33.Zhou, G.Q., Xu, M.L., Tan, Z., and Li, X. (1997). Effects of ecological factors of protein and amino acids of rice. Acta Ecol. Sin. 17: 5. 